Original Contribution

\title{
INFLUENCE OF SOME ROOTSTOCK ON THE GROWTH AND QUALITY OF THE VINE PLANTING MATERIAL OF THE MAVRUD VARIETY
}

\author{
M. Mihaylov* \\ Faculty of Agronomy, University of Forestry - Sofia, Bulgaria
}

\begin{abstract}
The direction related with production of vine planting material originated from the 19th century, after the advent of Phylloxera vastatrix F. in which a large part of the vineyards in Bulgaria and the main wine-growing countries were destroyed. Only solution was proposed for grafting vine varieties from Vitis vinifera L. on resistant rootstocks. A number of biological characteristics of the vine influence both the nursery for scions and the rootstock nursery. One of them, which is main is the affinity of different rootstocks on the different vine varieties. In the southern Bulgaria, where the Mavrud variety is characteristic, high losses are observed due to the low yield of first-class vines. In Bulgaria, the Mavrud variety is highly valued due to its biological qualities, resulting in extracts and dense red wines that have glorified our country.
\end{abstract}

Key words: Mavrud, vine nursery, rootstocks, grafting.

\section{INTRODUCTION}

In the 1980s, Republic of Bulgaria was ranked among a number of countries producing highquality grapes and wines such as France, Italy and Spain.

In the vine planting material production of Mavrud variety, there is unsatisfactory affinity for the American rootstocks used in our country, and thickening is formed at the place of grafting Mavrud variety shows little compatibility with the used in Bulgaria rootstocks. Best results were obtained with the rootstock - Rupestris du Lot, and the lowest with $41 \mathrm{~B}$ (1).

In the 1970 the vineyards areas in Bulgaria occupy a maximum of 207000 hectares, due to the transition to a market economy, the areas are significantly reduced after 1990, and at present, according to the data of MAF, Agrostatistic Department, the vineyards areas are 63953 ha in 2017 (2).

In 2016 was established that rootstock SO4 is not suitable for variety Nikopol Mavrud its get a 39 $\%$ of standart vines in the nursery ( 3 )

*Correspondence to: Marko Mihaylov, University of Forestry - Sofia, Faculty of Agronomy, 10 Kliment Ohridsky Blvd, 1797 Sofia, Bulgaria, Email: marko.mihaylovltu@gmail.com
Following the country's accession to the European Union in 2007, the import of vine planting material from non-EU countries such as Macedonia, Serbia, Moldova, Grapevine material imported into the country come from EU member states, with 9 million planted in 2007, 4 million planted in 2008, and nearly 420,000 in 2009.

The base call using of the rootstock largely determined by the graft.

With omega copulation, the formation of callus tissue is affected to a greater extent on the substrate as compared with the graft, but graft also has large influence of the regeneration processes. (4-5)

The aim of the study is to apply a suitable rootstock for the Mavrud variety.

\section{MATERIAL AND METHODS}

The research was conducted during the period 2017 - 2018 in the base for production of certified vine planting material of the company „AMV-Agro" Ltd, located in the village of Tsalapitsa, Plovdiv district. In the experiment are included local red wine variety - Mavrud omega grafted on rootstocks - Berlandieri x Riparia Teleki sel. Kober 5 BB, $\mathrm{BC}_{1}$ x 333 EM Fercal, Chaselas $\mathrm{x}$ Berlandieri $41 \mathrm{~B}$, Berlandieri $\mathrm{x}$ Rupestris 1103 Paulsen, Berlandieri x Riparia 
SO4, Berlandieri x Rupestris $140 \mathrm{Ru}$ and Berlandieri $x$ Rupestris $110 \mathrm{R}$.

In each variant, 700 grafted cuttings were included in 7 replicates of 100 cuttings by the fractional plot method.

Observing Regulation № 11 of 2 March 2014 of the MAF, the cuttings we collected were well ripened with a diameter of about $8 \mathrm{~mm}$ without any visible mechanical damages or curvatures. The maturity of the shoots was determined visually.

Grafting method was done by grafting machine (PM - 450) at the end of March. The vines in the research were grown by respecting all the requirements of the technology, which is based on raised bed rooting.

The vines were removed at the beginning of November with lift operating knife bracket.

\section{RESULTS AND DISCUSSION}

The increase of the average length of the shoots in the vine nursery during the two years of the research (2017-2018) is presented in (Figure 1).

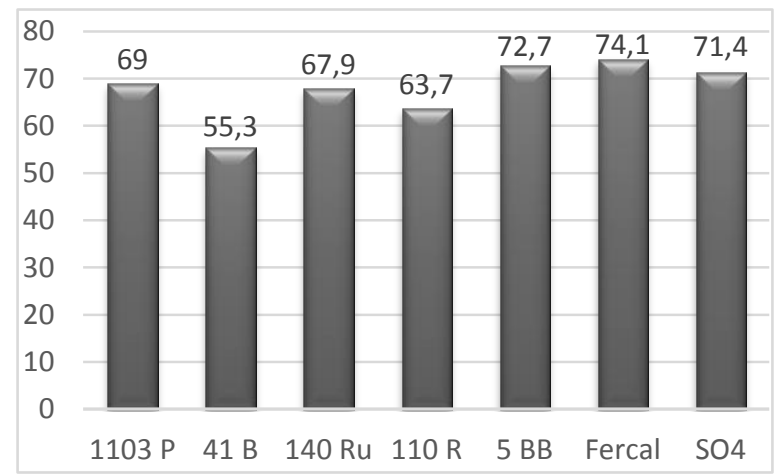

Figure 1. Length of the shoots of Marvud variety grafted onto different rootstocks in the nursery for the period 2017-2018 in centimeters.

It was established that with the highest growth rate of the shoots in the nursery, the Mavrud variety indicate grafted on rootstock Fercal - an average of $74,1 \mathrm{~cm}$, followed by $5 \mathrm{BB}-72,7 \mathrm{~cm}$ and $\mathrm{SO} 4-71,4 \mathrm{~cm}$. With unsatisfactory results in this indicator is found at rootstock $41 \mathrm{~B}-55,3$ $\mathrm{cm}$.

We noticed that after the stratification process, although between scion and rootstock formed a solder, much of the vines on $41 \mathrm{~B}$ rootstock did not grow and perish. In the course of the work it was found that the losses in the vine nursery of this rootstock were over $55 \%$, followed by the rootstocks $110 \mathrm{Ru}-47 \%$ and $110 \mathrm{R}-31 \%$.
The highest percentage of developed vines in the nursey was obtained at rootstock $1103 \mathrm{P}-80 \%$ (Table 1).

Table 1. Percentage of intercepted vines in the nursery from Mavrud variety for the period 2017-2018.

\begin{tabular}{|l|l|l|l|}
\hline № & \multicolumn{1}{|c|}{$\begin{array}{c}\text { Vine } \\
\text { rootstocks }\end{array}$} & $\begin{array}{c}\text { Percentage } \\
\text { of the } \\
\text { intercepted vines i } \\
\text { the vine } \\
\text { nursery }\end{array}$ & $\begin{array}{c}\text { Percentage } \\
\text { of perished } \\
\text { vines } \\
\text { in the } \\
\text { nursery }\end{array}$ \\
\hline 1 & $1103 \mathrm{P}$ & $80 \%$ & $20 \%$ \\
\hline 2 & $5 \mathrm{BB}$ & $77 \%$ & $23 \%$ \\
\hline 3 & SO4 & $73 \%$ & $27 \%$ \\
\hline 4 & Fercal & $72 \%$ & $28 \%$ \\
\hline 5 & $110 \mathrm{R}$ & $69 \%$ & $31 \%$ \\
\hline 6 & $140 \mathrm{Ru}$ & $53 \%$ & $47 \%$ \\
\hline 7 & $41 \mathrm{~B}$ & $45 \%$ & $55 \%$ \\
\hline
\end{tabular}

During the reporting period the vines were subjected to the same conditions, therefore the only logical explanation is the different compatibility of the rootstock to match the variety and form a single conductive system.

Following the regulation number 95 of 2006 of the Ministry of Agriculture and Forestry for trade in vine planting material - the plants were categorized (Table 2).

Table 2. Categorization of vine rootstocks grafted on Mavrud variety for the period 20172018.

\begin{tabular}{|l|l|l|l|}
\hline № & Vine rootstocks & $\begin{array}{l}\text { First-class vind } \\
\text { \% }\end{array}$ & $\begin{array}{l}\text { Other class } \\
\text { \% }\end{array}$ \\
\hline 1 & $5 \mathrm{BB}$ & 46,48 & 53,52 \\
\hline 2 & Fercal & 45,06 & 54,94 \\
\hline 3 & $41 \mathrm{~B}$, & 40,97 & 59,03 \\
\hline 4 & $1103 \mathrm{P}$ & 42,20 & 57,80 \\
\hline 5 & SO4 & 45,42 & 54,58 \\
\hline 6 & $140 \mathrm{R}$ & 39,96 & 60,04 \\
\hline 7 & $110 \mathrm{R}$ & 40,85 & 59,15 \\
\hline
\end{tabular}

After removing the vines in the beginning of November with lift operating knife bracket from vine nursery it was established that a high root system is formed on Mavrud variety grafted on rootstock $110 \mathrm{P}$ - average 9 roots with thickening $3,2 \mathrm{~mm}$, followed by $1103 \mathrm{P}-8,6$ roots with thickening $3,4 \mathrm{~mm}$, and $140 \mathrm{Ru}$ with 7,2 roots and thickening 4,4 $\mathrm{mm}$.

The highest percentage of first-class vines was obtained at rootstocks $5 \mathrm{BB}-46,48 \%$, followed by Fercal $-45,06 \%$ and SO $4-45,42 \%$. The lowest yield of first-class vines was obtained at $140 \mathrm{Ru}$. 


\section{CONCLUSIONS}

The growth rate of the shoots between 71-74 $\mathrm{cm}$ in the nursery, the Mavrud variety indicate grafted on rootstocks Fercal, $5 \mathrm{BB}$ and $\mathrm{SO} 4$.

Mavrud variety grafted on rootstocks $110 \mathrm{P}$, $1103 \mathrm{P}$ and $140 \mathrm{Ru}$ - formed between 7-9 roots with thickening 3-4 mm.

Based on the research conducted in 2017-2018, it was found that the Mavrud variety omega grafted on the rootstocks $-5 \mathrm{BB}$, Fercal, $41 \mathrm{~B}$, $1103 \mathrm{P}, \mathrm{SO} 4,140 \mathrm{R}$ and $110 \mathrm{P}$ highest percentage of first-class vines was established on rootstock - $5 \mathrm{BB}-46,48 \%$, followed by Fercal $-45,06 \%$ and SO4 $-45,42 \%$.

In the process of research, a high rate of perished vines $(55 \%)$ in the nursery was established from Mavrud variety grafted on rootstock $41 \mathrm{~B}$.

It was established positive correlation $(0,649)$ between intercepted vines in the vine nursery and the first-class vines.

\section{ACKNOWLEDGEMENTS}

The present study was initiated and implemented with the support of the National Science Program „Young Scientists and Postdoctoral Students“. We express our gratitude for the concern for the
MIHAYLOV M.

young researchers, scientists and professors of Bulgaria.

Gratitude for the opportunity to work and to gain experience in the base for production of vine planting material „AMV-Agro" Ltd, Tsalapitsa, Plovdiv. Special thanks to PhD. Veneta Yaneva for the cooperation and the valuable advice during my work.

\section{REFERENCES}

1. Lilov, D., Biological bases of affinity for the the vine. $B A S$, Sofia pp 31, 1979.

2. MAF., "Agrostatistic“ department., Grape and wine production - No 342, 2017.

3. Stalev, B., Dintchev I., Angelov, L. Janeva, V., Ivanov, V., Development of the SO4 Vine Rootstock in Wine, Table and Disease-Resistant Varieties after Callusing in Vine Nursery. Scientia Agriculturae, pp 334-337, 2016.

4. Angelov, L., Stalev, B., Dintchev, I., Ivanov, V., Janeva V., Research of Impact of Berlandieri x Riparia SO4 Rootstock on Callusing and Developed Buds of Wine, Table and Disease-Resistant Varieties after Callusing. Scientia Agriculturae, pp 216219, 2016

5. Kara, S., Effects of different quality of vine plant material development and vine plants productivity. Kishinev, Thesis, pp 188, 2010 . 
MIHAYLOV M. 